\title{
Cell Transplantation as a Method to Investigate Spinal Cord Regeneration in Regenerative and Nonregenerative Xenopus Stages
}

\author{
Emilio E. Méndez-Olivos ${ }^{1}$ and Juan Larraín ${ }^{1,2}$ \\ ${ }^{1}$ Center for Aging and Regeneration, Faculty of Biological Sciences, Pontificia Universidad Católica de Chile, \\ Alameda 340, Santiago, Chile
}

\begin{abstract}
Mammals are not capable of regenerating their central nervous system (CNS); anamniotes, however, can regenerate in response to injury. The mechanisms that explain the different regenerative capabilities include: (i) extrinsic mechanisms that consider the cellular environment and extracellular matrix composition, (ii) intrinsic factors implicating the presence or absence of genetic programs that promote axon regeneration, and (iii) the presence or absence of neural stem and progenitors cells (NSPCs) that allow neurogenesis. Xenopus laevis is able to regenerate its CNS during larval stages (i.e., the regenerative stage [R-stage]). However, concomitant with metamorphosis this capacity decreases and is lost completely in juvenile froglets (i.e., nonregenerative stages [NR-stages]). The loss of the regenerative ability correlates with a reduction in the percentage of $\mathrm{Sox} 2^{+}$cells, which are putative NSPCs. This protocol shows the effect of transplantation of spinal cord cells from R-stage Xenopus larvae into NR-stage froglets. Using this procedure, it is possible to study axon regeneration and stem cell biology in vivo.
\end{abstract}

It is essential that you consult the appropriate Material Safety Data Sheets and your institution's Environmental Health and Safety Office for proper handling of equipment and hazardous materials used in this protocol.

RECIPES: Please see the end of this protocol for recipes indicated by $<R>$. Additional recipes can be found online at http://cshprotocols.cshlp.org/site/recipes.

\section{Reagents}

Bovine serum albumin (BSA; $0.5 \mathrm{mg} / \mathrm{mL}$ in L-15 Medium)

Ethyl 3-aminobenzoate methanesulfonate salt $(0.02 \%$ [w/v] in 0.1× MBS [MS-222; Sigma-Aldrich A5040])

The solution can be stored for 1 mo at $4^{\circ} \mathrm{C}$.

Fibrinogen (100 mg/mL in phosphate-buffered saline [PBS]; Sigma-Aldrich F6755)

Final medium $<\mathrm{R}>$

L-15 Medium (Sigma-Aldrich L4386)

${ }^{2}$ Correspondence: jlarrain@bio.puc.cl

From the Xenopus collection, edited by Hazel L. Sive.

(C) 2018 Cold Spring Harbor Laboratory Press

Cite this protocol as Cold Spring Harb Protoc; doi:10.1101/pdb.prot101006 
E.E. Méndez-Olivos and J. Larraín

Modified Barth's solution (MBS) $(1 \times)<\mathrm{R}>$

Penicillin

StemPro Accutase cell dissociation reagent (Gibco A1110501)

This enzyme has protease and collagenase activity to allow tissue and cell dissociation.

Streptomycin

Thrombin (Sigma-Aldrich T5772; $100 \mathrm{U} / \mathrm{mL}$ in PBS)

Thrombin cleaves fibrinogen into fibrin to form a clot.

Trypan Blue solution (Sigma-Aldrich T8154)

Trypan Blue is a vital stain that allows discrimination between dead and living cells because it is only incorporated by cells with a damaged membrane.

Xenopus laevis animals (stages NF50 and NF66; Nieuwkoop and Faber 1994)

Transgenic animals make the identification of donor and host cells easier.

Equipment

Forceps (e.g., FST, Student Dumont \#5)

Hemocytometer

Light source (e.g., Fiber-Lite Mi-150 Illuminators [Dolan-Jenner])

Microcentrifuge

Microscissors, straight (e.g., Vannas-Tübingen spring scissors [FST 15003-08])

Needle (23-g) (optional; see Step 13)

Parafilm M (Sigma-Aldrich P7793)

Petri dish (glass, 100-mm)

Stereomicroscope (e.g., Nikon, SMZ745T)

Tissue paper (e.g., Kimwipes)

Tubes (microcentrifuge, $1.5-\mathrm{mL}$ )

Vortex mixer (e.g., V1 Plus [Boeco])

METHOD

Spinal Cord Isolation and Tissue Dissociation

Use three to four tadpoles to obtain sufficient cells per each froglet to be transplanted.

1. Place a larva at NF Stage 50 into a Petri dish with $50 \mathrm{~mL}$ of MS-222. After $3 \mathrm{~min}$, check for an escape reflex.

The absence of a response indicates that the animal is anesthetized.

2. Transfer the larva to a dissection surface under the stereomicroscope.

3. Remove and discard the head and the posterior third of the tail.

4. Holding the remaining part of the trunk, use tweezers to pull the spinal cord out of the body. See Troubleshooting.

5. Transfer the spinal cord to a $1.5-\mathrm{mL}$ microcentrifuge tube containing $500 \mu \mathrm{L}$ of Accutase. Seal the tube with Parafilm.

i. Incubate at room temperature with agitation (e.g., using a vortex mixer) for $1 \mathrm{~h}$.

ii. To avoid having the spinal cords adhere to the walls of the tube, mix the tubes by manual inversion every $15 \mathrm{~min}$.

6. Add $1 \mathrm{~mL}$ of $0.5 \mathrm{mg} / \mathrm{mL}$ BSA in L-15 Medium to inactivate the Accutase.

7. Pellet the cells by centrifugation at $200 \mathrm{~g}$ for $5 \mathrm{~min}$. Resuspend the pellet in $1 \mathrm{~mL}$ of final medium. 
8. Stain a $10-\mu \mathrm{L}$ aliquot with trypan blue. Count the cells using a hemocytometer. See Troubleshooting.

9. Pellet the cells again by centrifugation at $200 \mathrm{~g}$ for $5 \mathrm{~min}$. Carefully remove and discard the supernatant.

10. Resuspend the cells in final medium to attain a concentration of $1 \times 10^{5}$ cells $/ \mu \mathrm{L}$. There is no need for further supplementation with growth factors.

\section{Spinal Cord Resection}

11. Place a froglet at NF Stage 66 into a Petri dish containing $50 \mathrm{~mL}$ MS-222 for $10 \mathrm{~min}$. Check for the absence of an escape reflex.

See Troubleshooting.

12. Place the froglet under a stereomicroscope.

13. Using microscissors (or a 23-g needle) as a scalpel, open the dorsal skin with a longitudinal cut above the spinal cord between the fifth and sixth vertebrae.

14. Carefully lift the dorsal muscles to expose the vertebrae.

15. To expose the spinal cord, use a pair of tweezers to perform a dorsal laminectomy and remove the fifth and sixth vertebrae.

16. Using microscissors, perform a 1-mm resection of the spinal cord. Make sure that no uninjured nerve tracts are left.

17. Blot the area using tissue paper until bleeding stops. Leave a cavity between both stumps to place the cells.

\section{Transplantation Procedure}

18. Mix $1 \mu \mathrm{L}$ of the cell suspension $\left(1 \times 10^{5}\right.$ cells $\left./ \mu \mathrm{L}\right)$ obtained from the NF Stage 50 spinal cord (Step 10) with $0.5 \mu \mathrm{L}$ of fibrinogen and $0.5 \mu \mathrm{L}$ of thrombin.

Clot formation will begin as soon as the thrombin and fibrinogen mix. The growth factors in the suspension are diluted to a final concentration of $10 \mathrm{ng} / \mathrm{mL}$.

19. Immediately transfer the mixture to the resected site using a micropipette. See Troubleshooting.

20. Two minutes after cell transplantation, reappose the dorsal muscle and skin. Hold closed with tweezers for a few seconds.

Avoid disturbing the clot in the spinal cord.

21. Carefully transfer the froglet to a recipient Petri dish containing $0.1 \times$ MBS supplemented with penicillin $(100 \mu \mathrm{g} / \mathrm{mL})$ and streptomycin $(100 \mu \mathrm{g} / \mathrm{mL})$. Use a volume just sufficient to cover the animal.

See Troubleshooting.

Problem (Step 4): The spinal cord breaks during the dissection.

Solution: Try to remove the surrounding muscle to expose the spinal cord before pulling it out. 
E.E. Méndez-Olivos and J. Larraín

Problem (Step 8): Low amount of living cells or clusters of cells

Solution: We use 60 spinal cords per $\mathrm{mL}$ of the enzyme. With higher numbers, there is no guarantee of a good yield.

Problem (Step 11): Froglets are still awake after 10 min.

Solution: Froglets weighing $1 \mathrm{~g}$ or less should be anesthetized in $10 \mathrm{~min}$. Larger animals take longer.

Problem (Step 19): The quantity of liquid overflows the injury site.

Solution: The cavity should hold up to $2 \mu \mathrm{L}$. If the liquid overflows the site, check the size of resection. Larger volumes require larger pieces to be resected.

Problem (Step 21): The froglets die soon after the surgery.

Solution: Allow the animals to recover in a volume just barely sufficient to cover, as they will be unable to swim to reach the surface to breathe.

\section{DISCUSSION}

This procedure was adapted from transplantation experiments performed in rats (Lu et al. 2012). Here we use froglets at NF Stage 66 (Nieuwkoop and Faber 1994) as host, but we have obtained very similar results using NF Stage 56. It takes twenty to thirty days for the transplanted cells to populate the lesion site; their progression can be studied using classic hematoxylin and eosin staining of paraffin or cryosections. Although the histological organization is sufficiently different between donor and host tissue, the use of transgenic animals expressing fluorescent proteins in a tissue-specific manner makes the distinction between the two easier. Transplanted animals can be maintained up to $60 \mathrm{~d}$ without problems. The efficiency of this procedure can be improved by testing other growth factors (as was demonstrated on rodents [Lu et al. 2012]), performing transplantations at different days after resection, making the lesion in an anterior part of the spinal cord, or using animals at different stages as donors or hosts. The effects of immunosuppressing the host froglets can also be tested by thymectomy, as previously performed in limb transplantation experiments (Lin et al. 2013).

This procedure is compatible with anterograde tracing to study axon regeneration, gain- and lossof-function experiments, pharmacological studies, and functional recovery analysis. Given that there is no regeneration after transection in froglets (Beattie et al. 1990; Gaete et al. 2012; Muñoz et al. 2015), this procedure provides an opportunity to understand the mechanisms that allow NSPCs to improve spinal cord regeneration, a process that has been poorly studied (Assinck et al. 2017).

Final Medium

Reagent

BDNF (R\&D Systems 248-BD-025/CF)

Bovine serum albumin (Sigma-Aldrich)

EGF (R\&D Systems 2028-EG-200)

FGF (R\&D Systems 3139-FB-025/CF)

Prepare fresh in L-15 Medium (Sigma-Aldrich L4386).
Final concentration

$20 \mathrm{ng} / \mathrm{mL}$

$0.5 \mathrm{mg} / \mathrm{mL}$

$20 \mathrm{ng} / \mathrm{mL}$

$20 \mathrm{ng} / \mathrm{mL}$ 


$\begin{array}{lr}\mathrm{CaCl}_{2} & 0.41 \mathrm{~mm} \\ \mathrm{Ca}\left(\mathrm{NO}_{3}\right)_{2} & 0.33 \mathrm{~mm} \\ \mathrm{HEPES} & 10 \mathrm{~mm} \\ \mathrm{KCl} & 1.0 \mathrm{~mm} \\ \mathrm{MgSO}_{4} & 0.82 \mathrm{~mm} \\ \mathrm{NaCl} & 88 \mathrm{~mm} \\ \mathrm{NaHCO}_{3} & 2.4 \mathrm{~mm}\end{array}$

Adjust the $\mathrm{pH}$ to 7.4 . Prepare as a $10 \times$ solution and then autoclave. Store at $4{ }^{\circ} \mathrm{C}$ for up to $1 \mathrm{mo}$. Dilute to $0.1 \times$ and add antibiotics before use, and store for up to $3 \mathrm{~d}$.

\section{ACKNOWLEDGMENTS}

This work was supported by funds from CARE Chile UC-Centro de Envejecimiento y Regeneración (PFB 12/2007), Fondo Nacional de Desarrollo Científico y Tecnologíco (FONDECYT) (1141162) to J.L. E.E.M.O. is a Comisión Nacional de Investigación Científica y Tecnológica (CONICYT) Ph.D. fellow 21120400.

\section{REFERENCES}

Assinck P, Duncan GJ, Hilton BJ, Plemel JR, Tetzlaff W. 2017. Cell transplantation therapy for spinal cord injury. Nat Neurosci 20: 637-647.

Beattie MS, Bresnahan JC, Lopate G. 1990. Metamorphosis alters the response to spinal cord transection in Xenopus laevis frogs. J Neurobiol 21: $1108-1122$.

Gaete M, Muñoz R, Sánchez N, Tampe R, Moreno M, Contreras EG, Lee-Liu D, Larraín J. 2012. Spinal cord regeneration in Xenopus tadpoles proceeds through activation of Sox2-positive cells. Neural Dev 7: 13.

Lin G, Chen Y, Slack JMW. 2013. Imparting regenerative capacity to limbs by progenitor cell transplantation. Dev Cell 24: 41-51.
Lu P, Wang Y, Graham L, McHale K, Gao M, Wu D, Brock J, Blesch A, Rosenzweig ES, Havton LA, et al. 2012. Long-distance growth and connectivity of neural stem cells after severe spinal cord injury. Cell 150: 1264-1273.

Muñoz R, Edwards-Faret G, Moreno M, Zuñiga N, Cline HT, Larraín J. 2015. Regeneration of Xenopus laevis spinal cord requires Sox $2 / 3$ expressing cells. Dev Biol 408: 229-243.

Nieuwkoop PD, Faber J (eds.). 1994. Normal table of Xenopus laevis (Daudin): A systematical \& chronological survey of the development from the fertilized egg till the end of metamorphosis. Garland Publishing, New York. 


\section{Cell Transplantation as a Method to Investigate Spinal Cord Regeneration in Regenerative and Nonregenerative Xenopus Stages}

Emilio E. Méndez-Olivos and Juan Larraín

Cold Spring Harb Protoc; doi: 10.1101/pdb.prot101006 originally published online May 16, 2018

\begin{tabular}{|c|c|}
\hline $\begin{array}{l}\text { Email Alerting } \\
\text { Service }\end{array}$ & Receive free email alerts when new articles cite this article - click here. \\
\hline $\begin{array}{l}\text { Subject } \\
\text { Categories }\end{array}$ & $\begin{array}{l}\text { Browse articles on similar topics from Cold Spring Harbor Protocols. } \\
\text { Cell Biology, general (1382 articles) } \\
\text { Developmental Biology (728 articles) } \\
\text { Neuroscience, general (357 articles) } \\
\text { Stem Cells (46 articles) } \\
\text { Stem Cells, general (70 articles) } \\
\text { Xenopus (210 articles) }\end{array}$ \\
\hline
\end{tabular}

